\title{
A arte de narrar a história de uma vida em Orhan Pamuk: POSSÍVEIS APROXIMAÇÕES COM AS IDEIAS DE SiGMUND FREUD http://dx.doi.org/10.1590/1984-0292/1320
}

\author{
Jaquelina Maria Imbrizi , Fernanda Kanada Matsubara, \\ Mayara Lima Ferreira da Silva \\ Universidade Federal de São Paulo, Santos, SP, Brasil
}

\section{RESUMO}

Este ensaio objetiva discutir alguns trechos do livro Istambul: Memória e Cidade. Nessa obra, a arte de narrar a história de uma vida está em articular memória coletiva, trajetória singular e a hüzün, o afeto compartilhado pelos habitantes da cidade. As autoras exercitam a reflexão sobre o pensamento que está contido na arte da escrita e estabelecem possíveis aproximações "entre" dois campos diversos do saber: a literatura de Orhan Pamuk e a psicanálise de Sigmund Freud. Nessa aproximação, são destacados: a melancolia, o estranhamento e o processo de criação do romancista que faz eco com as pulsões de vida.

Palavras-chave: narrativa de história de vida; o pensamento da arte; melancolia; memória coletiva; literatura e psicanálise.

\section{THE ART OF NARRATING THE STORY OF A LIFE IN ORHAN PamuK: Possible approaches to the ideas of Sigmund Freud}

\begin{abstract}
This paper discusses some excerpts from the book Istanbul: Memories and the City. In this work, the art of narrating the story of a life is to articulate collective memory, singular trajectory and hüzün, affection shared by the inhabitants of the city. The authors exercite reflection about the thought that is contained in the art of writing and establish possible similarities "between" two different fields of knowledge: Orhan Pamuk's literature and Sigmund Freud's psychoanalysis. In this approach, are highlighted: melancholy, alienation and the creation of the novelist that echoes the life drives process.
\end{abstract}

Keywords: narrative of history of life; the thought of art; melancholy; collective memory; literature and psychoanalysis.

\footnotetext{
^Endereço para correspondência: Universidade Federal de São Paulo - Campus Baixada Santista, Público. Rua Silva Jardim - lado par - Vila Matias. 11015020 - Santos, SP - Brasil. E-mail: jaque. imbrizi@gmail.com,fernanda_matsubara@yahoo.com.br, mayara_1fs@hotmail.com
} 
[...] a psicanálise é marcada pela autoridade do poeta, aquele que está, permanentemente, à frente da ciência na percepção dos afetos (FUKS, 2009, p. 17).

Ao lermos o romance Istambul: memória e cidade, somos surpreendidos pela generosidade de Orhan Pamuk (2007a), pois esse romancista compartilha suas experiências com seus leitores, muitas delas vinculadas aos encontros com as pessoas, à arquitetura, à topografia, à história e à luz peculiar da cidade turca. Assim, ele produz uma narrativa profícua, na primeira pessoa do singular, acerca de sua trajetória de vida. Ao manusearmos a capa da edição brasileira do livro, entramos em contato com a fotografia de uma criança, curiosa, assustada e melancólica, tendo ao fundo o Estreito de Bósforo e algumas imagens de prédios e torres de arquitetura otomana. Ao folhearmos o livro, somos agraciados ainda com memórias pessoais do autor entremeadas a fotos, gravuras, cartões-postais e quadros que retratam Istambul. Parece que a intenção dos editores e do autor é aguçar os sentidos dos leitores, apresentando as várias facetas que compõem essa obra de arte:

I) A beleza e a estranheza na literatura de Pamuk: o amor do autor por sua terra natal, ao mesmo tempo em que o autoriza a retratar a maravilhosa paisagem de Istambul, não o isenta de reconhecer a pobreza que assola a cidade. Mais do que isso, o escritor insiste na estranha aventura de delinear um afeto peculiar que, segundo ele, é comum aos habitantes desse território: a hüzün.

II) O pensamento por imagens - o processo de criação do autor: o romancista compartilha conosco o percurso que se inicia com os primeiros desenhos na infância e desemboca nos escritos literários na idade adulta. Nesse itinerário, produz reflexões sobre seu processo de criação. Assim, nos oferta pensamentos e escritos produzidos por meio de imagens, pois entre suas fontes de inspiração estão a fotografia, as gravuras, cartões-postais e pinturas cujo tema é a cidade de Istambul.

Nosso objetivo neste artigo é apresentar essas duas facetas da arte, presentes no citado romance de Orhan Pamuk, de modo a aproximá-las das ideias de Sigmund Freud, pois partimos do princípio de que ambos os autores estão interessados nas experiências que tecem a vida e que podem aproximá-la da arte. Mais especificamente, os dois se deslocam dentro do regime estético da arte. Pois, para Rancière (2009, p. 10), esse regime dá o testemunho: “[...] de certa relação do pensamento com o não pensamento, de certa presença do pensamento na materialidade sensível, do involuntário no pensamento consciente e do sentido no insignificante".

Quanto ao nosso método de trabalho, escolhemos alguns trechos do livro Istambul: memória e cidade e fizemos um exercício de aproximação com cinco textos de Freud: "Escritores criativos e devaneio" (1976a[1908]), "A transitoriedade" (2010a[1916]), "Luto e Melancolia" (2010b[1917]), "O "Estranho", (1976b[1919]) e "O Mal-estar na Civilização" (2010c[1930]). As articulações entre as ideias dos dois autores foram realizadas de modo a englobar as duas facetas da arte que são desenvolvidas no decorrer do texto. Como também foi possível inserir as produções de Freud e Pamuk naquilo que Rancière (2009) denomina de revolução propiciada pelo regime estético da arte: a identidade dos contrários, 
um saber que se define como determinado afeto, a ambiguidade do sujeito e dos temas desenvolvidos, o confronto com o desconhecido, a identificação da modalidade inconsciente do pensamento e a abolição de um conjunto ordenado de relações entre o visível e o dizível.

\section{A beleza e a estranheza na literatura de Pamuk}

Podemos chamar de melancolia esse estado confuso e nebuloso, ou talvez devamos chamá-lo por seu nome turco, hüzün, que denota uma melancolia antes compartilhada do que particular. Sem oferecer qualquer clareza, e em vez disso velando a realidade, a hüzün nos traz conforto, atenuando a aspereza dos traços da paisagem como a condensação que se forma na janela quando uma chaleira emite vapor numa tarde de inverno (PAMUK, 2007a, p. 98).

No texto "O 'Estranho", Freud (1976b[1919]), ao analisar alguns escritores da literatura fantástica, indica um afeto que se refere ao estranho familiar que está presente em várias experiências advindas do contato do sujeito com a arte. Para ele, esse afeto está associado à vertente um pouco negligenciada da estética, que não está preocupada com o estudo da beleza, mas com a "[...] teoria das qualidades do sentir". O psicanalista, então, nos brinda com a discussão sobre a angústia produzida no sujeito, ao se deparar com obras de arte que não pretendem apaziguar, mas sim gerar desconforto no receptor. Mais do que isso, Freud (1976b[1919], p. 275-282) afirma que o estranho está relacionado a "[...] tudo o que deveria ter permanecido secreto e oculto, mas veio à luz" e que reaviva a percepção do desamparo inerente ao ser humano. Nesse sentido, é como se pudéssemos derivar uma estética negativa em oposição a uma estética do agradável, na qual "[...] a verdade do desejo não reconhece as fronteiras do feio e do bonito, do horror e do sublime" (SOUZA, 2001, p. 128). O horror e a angústia aqui estão relacionados ao fato de que o sujeito, ao se deparar com o estranho que é também familiar, não só entra em contato com conteúdos recalcados, que até aquele momento estavam distantes de sua consciência, mas também sofre uma experiência subjetiva de descentramento do $\mathrm{Eu}$, de perda dos limites entre o $\mathrm{Eu}$ e o mundo externo. Para este autor, é possível pensar essa perda como aquisição, pois o Eu não é uno e funda-se sob a lógica do múltiplo.

Nesse texto também Freud analisa a forma como alguns escritores pretendem provocar certo desconforto em seus leitores, seja pelo tipo de tema escolhido, seja pela posição ocupada pelo narrador que, em alguns casos, não oferece esclarecimentos no desenrolar nem no final da trama, mas sim oferta a revelação do inusitado e do que causa perplexidade. Como exemplo, Freud cita Hoffmann (1776-1822) como o inigualável mestre do estranho na literatura, por abusar do pensamento mágico, das ambiguidades, dos assuntos repetitivos, dos personagens duplos e por dar vida ao inanimado. Para Martini e Coelho Junior (2010), todas essas características juntas não necessariamente provocariam a sensação de estranhamento nos leitores; antes seria necessária a reativação de um funcionamento primitivo do psiquismo. 
Ou seja, é necessária uma experiência vivida subjetivamente pelo Eu e que coloque sua identidade em questão. O estranho nesse contexto estaria relacionado à experiência dos limites do $\mathrm{Eu}$, pois a oposição entre o familiar e o estrangeiro retoma distinções mais primitivas entre Eu/não Eu ou dentro e fora. Para provocar essa experiência no sujeito, é necessário que o escritor tenha a habilidade de produzir um fator narrativo que coloque o leitor no centro da experiência do estranho. Para isso, há que se narrar de modo a exceder a mera comunicação e não depender somente do entendimento intelectual da trama apresentada.

É no capítulo 10 do livro Istambul que nos deparamos com uma estranha temática: a tentativa de Pamuk de retratar de modo palpável a hüzün, um afeto específico delineado por ele e que se refere ao sentimento compartilhado por todos os habitantes dessa cidade. Em trabalho anterior (IMBRIZI; MATSUBARA; SILVA, 2013), analisamos que o autor desenvolveu uma sensibilidade aguçada ao mergulhar em sua própria cultura a ponto de descrever esse afeto, que tem algo em comum com os sentimentos de tristeza e melancolia, mas que se refere também à peculiaridade que só a palavra turca consegue decifrar.

O romancista alude à concepção de melancolia em Robert Burton (15771640), que associa esse afeto a uma solidão feliz e pressupõe que ele fortaleceria os poderes imaginativos do sujeito. Assim, diferentemente da melancolia, que é um sentimento solitário, a hüzün é compartilhada e nela todos os habitantes se veem refletidos. Em sua raiz árabe, a palavra transmite uma sensação de perda espiritual profunda. Em sua base religiosa, para o sufismo, trata-se de uma angústia vinculada tanto à impossibilidade de se aproximar de Alá quanto ao fato de que a pessoa investiu em demasia nos prazeres mundanos. Para o autor, não basta examinar a palavra, há que evocar o estado de espírito provocado pela música e a poesia de seu povo, e retomar um modo de encarar o mundo que "[...] no final das contas tanto afirma quanto nega a vida" (PAMUK, 2007a, p. 101). Contudo, o ponto de partida do autor para retratar esse sentimento é "[...] a emoção que uma criança pode sentir quando olha para uma janela embaçada" (PAMUK, 2007a, p. 102). Em síntese, a hüzün é uma palavra ambígua que se relaciona com um conceito poético, um estado de graça e uma doença.

Há afinidade com a tristesse, descrita por Claude Lévi-Strauss (19082009), pois a fragilidade da vida das pessoas, o modo como tratam umas às outras e a distância que sentem dos centros do Ocidente fazem com que os viajantes estrangeiros atribuam um "ar misterioso" à cidade. Assim como a huzün, a tristesse é um sentimento compartilhado, "uma atmosfera e uma cultura comuns a milhões de pessoas" (PAMUK, 2007a, p. 110). O que os diferencia é que a tristeza que assola Istambul está vinculada ao fato de que os Istanbullus levam suas vidas em meio às ruínas de uma gloriosa civilização do passado. O que para os escritores e viajantes estrangeiros pode ser fonte de admiração, "[...] para os residentes mais sensíveis e atentos da cidade, essas ruínas lembram que a cidade atual é tão pobre e confusa que nunca mais poderá sonhar ascender às suas alturas passadas de riqueza, poder e cultura" (PAMUK, 2007a, p. 112). Outro ponto de diferenciação é que a tristesse pressupõe um ocidental assolado pela culpa observando a pobreza das cidades tropicais, enquanto a hüzün é um sentimento de quem pertence à 
cidade e está imerso nela. Ao mesmo tempo em que pode produzir paralisia nos habitantes de Istambul, ela lhes "[...] concede uma licença poética para sua paralisia” (PAMUK, 2007a, p. 113-114).

Nesses trechos, o estranhamento está relacionado à ousadia do escritor em retratar um afeto que somente os habitantes da cidade de Istambul podem compartilhar e que só a palavra turca hüzün consegue significar, como também está conectado ao fato de que o romancista coloca em palavras e explicita aquilo que era para permanecer velado e recalcado: o quanto cada Istanbullu está impregnado da história pregressa contida na paisagem da cidade, que lateja na memória de seus habitantes. É como se a topografia da cidade tivesse marcado o modo de estar no mundo das pessoas que nasceram em Istambul ou a escolheram para viver. É nesse sentido que a narrativa de Pamuk compartilha com o leitor a experiência dos limites do Eu, certa indistinção entre o que é singular no sujeito e aquilo que faz parte de sua cultura, mas que o impregna a despeito de sua consciência ou não do fato. Realidade, mito, fantasia, racionalidade e irracionalidade misturam-se nessa escrita de si do romancista e podem produzir, como efeito narrativo, a sensação de estranhamento em seu leitor.

\section{I.1. HÜZÜN, LUTO E MELANCOLIA}

No texto "Luto e Melancolia", Freud (2010b[1917], p. 172) afirma que o luto se refere a uma perda de um objeto real e a melancolia estaria relacionada com a perda do próprio Eu que, identificado com o amor ao objeto perdido, real ou imaginário, acaba por se transformar momentaneamente no objeto. Este pode estar relacionado com as escolhas afetivas do sujeito: "[...] a pessoa amada ou [...] uma abstração, que ocupa seu lugar, como pátria, liberdade, um ideal etc."

O psicanalista aponta que tanto no luto quanto na melancolia há, concomitantemente à perda do objeto, a emergência de sentimentos ambivalentes frente ao que foi perdido. A diferença é que na melancolia há a "regressão da libido para o Eu" e, assim, a ambivalência se instaura contra o próprio Eu e atua como uma dolorosa ferida que rebaixa a autoestima.

No texto "A Transitoriedade", Freud (2010a[1916], p. 252) afirma que a revolta psíquica pela perda de um objeto pode impedir a fruição do belo e transitório, e parece ser esta a afecção vinculada à melancolia. Nela, o sujeito se paralisa frente às perdas, identifica-se com o que foi perdido e, assim, tem dificuldades em investir em novos objetos do mundo. Em alguns casos, com o passar do tempo, há possibilidades de essa paralisia ser superada e, assim, produzir a percepção de que "[...] a nossa elevada estima dos bens culturais não sofreu com a descoberta da sua precariedade". Os processos de criação e fantasia parecem se alimentar dessas perdas e da capacidade de superá-las. Após o transcorrer do tempo, o sujeito poderia inventar novos objetos, reinventando aquilo que foi perdido, pois, para Freud (1976a[1908]), os artistas, e principalmente os escritores criativos, desenvolveram a habilidade de criar um mundo próprio e reajustam os elementos da realidade de outra forma que lhe seja mais confortável e que possa fazê-los estar mais próximos daquilo que desejam. $\mathrm{O}$ devanear e o fantasiar que fazem 
parte das invenções, da capacidade de desenvolver o senso de humor no adulto e do brincar da criança são um modo de transformação da realidade, pois "[...] toda fantasia é a realização de um desejo, uma correção da realidade insatisfatória" (FREUD, 1976a[1908], p. 152).

Se no texto de Freud o objetivo é analisar um afeto que remonta a história de todo indivíduo em seu processo de constituição e é assim compreendido como universal e parte da dinâmica inconsciente/consciente própria às perdas de objeto, na hüzün, retratada por Pamuk, há uma ênfase naquilo que pode ser compartilhado por cada transeunte da cidade, mas que, também, não necessariamente, seria consciente. Esta parece ser a maestria do romancista: trazer à consciência esse afeto, a ponto de explicitá-lo em palavras escritas e imagéticas. Quem sabe seja esse um bom movimento para desconstruir o que escraviza os Istanbullus a esse sentimento, que acaba por produzir, em alguns casos, um empobrecimento do Eu.

Um sujeito poderia se deleitar com o passado perdido de uma cidade gloriosa a ponto de absorver a melancolia que exala dela? Parece que sim! Para Pamuk, a perda de objeto que produz a hüzün e que assola Istambul se refere ao passado suntuoso do Império Otomano, que, ao que tudo indica, não volta mais. Algo que está no imaginário de seus habitantes e que também se revela na concretude dos prédios de fachada descolorida e sem manutenção. É o preto e branco que assola a arquitetura da cidade: "Adoro a melancolia dominante quando contemplo as paredes dos antigos prédios de apartamentos e as fachadas escuras dos maltratados e decaídos casarões de madeira precisados de pintura; só em Istambul encontrei essa textura, esses matizes" (PAMUK, 2007a, p. 44). Nesse sentido, a hüzün não seria uma doença, mas um estado de espírito e, para alguns, uma licença poética que, no caso do autor, lhe oferece o sustentáculo para os processos de criação.

Por mais contraditório que possa parecer à primeira vista, é um processo de criação que se inspira nas ruínas da cidade, naquilo que ela foi e que ficou perdido no tempo. Amar o transitório, amar não só a cidade, mas também as lembranças de um passado. Assim, a melancolia de Istambul é perene, na qual passado e presente convivem em profusão, e às vezes temos a impressão de que é mais passado do que presente. Mas é um passado calcado na nostalgia daquilo que foi o período glorioso da cidade. Há ambiguidades na escrita do autor, tanto no fato de que ele enxerga beleza e feiura nas ruínas de sua cidade, inerentes a seus matizes peculiares, quanto no fato de que ele constata perenidade e transitoriedade na história de sua terra natal. Isso é possível verificar no trecho a seguir:

Se eu fosse dar conta da hüzün que Istambul me fez sofrer na infância, precisaria descrever toda a história da cidade desde a destruição do Império Otomano e - ainda mais importante a maneira como essa história se reflete nas 'lindas' paisagens da cidade e do seu povo (PAMUK, 2007a, p. 101). 
Nessa citação, parece que o romancista revela que também se alimenta, desde a infância, da melancolia e que ela é uma das fontes de sua inspiração poética. Apesar de destruída, a época do império insiste em estar presente nos territórios físico e existencial dos Istanbullus.

Há ainda outra forma de expressão da ambiguidade, que está no fato de que o escritor mescla os sentimentos de vergonha e orgulho por sua cidade natal. Em muitas passagens, não esconde a paixão vinculada ao fato de ser habitante de uma cidade com suas particularidades arquitetônicas e atravessada pelo Bósforo. São longos os trechos de declaração de amor à paisagem que emana desse estreito, que marca os limites entre os continentes asiático e europeu na Turquia. Por outro lado, em alguns trechos encontramos, entremeado às descrições da cidade, certo sentimento de vergonha frente à decadência de suas fachadas sem manutenção:

Da mesma forma, quando vejo a escuridão cair aos poucos como um poema sobre a luz fraca dos lampiões de rua para engolir esses velhos bairros, sinto-me reconfortado de saber que, pelo menos por aquela noite, estaremos a salvo; a vergonhosa pobreza de nossa cidade ficou oculta aos olhos ocidentais (PAMUK, 2007a, p. 45).

A partir dessa citação, podemos afirmar que o que possibilita o sentimento de orgulho é o passado glorioso da cidade e o que fortalece a vergonha são as ruínas das ruas. Ao mesmo tempo em que são estas também que oferecem a textura e os matizes pelos quais o escritor tem tanto apreço, e que oferecem as bases para a reflexão acerca da ambiguidade de sentimentos suscitados por sua experiência nesse território. Exercita o papel de narrador que visa produzir não o esclarecimento em seus leitores sobre o que é escolher viver nesse território, mas sim algo inquietante e enigmático.

\section{I.2. HÜZÜN E SENTIMENTO DE CULPA}

O mito é um instrumento privilegiado de reflexão crítica sobre a dimensão inconsciente - sexualidade e morte - dos fenômenos coletivos (FUKS, 2009, p. 29).

No texto "O Mal-estar na Civilização", Freud (2010b[1917], p. 106) analisa a angústia dos homens inerente ao processo de socialização. Essa angústia está associada ao mito que fundou a cultura que, do ponto de vista da herança arcaica, se refere à morte do pai "não castrado" orquestrada pela rebelião dos irmãos. Esse mito é reavivado na história singular de cada sujeito, e é despertado no modo como ele vivencia e experimenta os afetos ambíguos com seus familiares ou pessoas mais próximas. Amor e ódio, os fantasmas da sexualidade e da morte também estão presentes em outro mito, inspirado na tragédia grega de Sófocles, o complexo de Édipo. O sujeito, assim, é fruto de um tempo passado da espécie e da história psíquica; filogenia e ontogenia o configuram, o compõem e o constituem. Pois, para Freud (2010c[1930], p. 24), "[...] o que passou pode ficar conservado na vida psíquica, não tem necessariamente que ser destruído". 
Para Fuks (2009, p. 28), a morte e seu reconhecimento encontram-se na origem da moral, da religião e das organizações sociais e, portanto, o recalque do desejo do incesto e do assassinato é a base do direito do indivíduo à filiação simbólica.

O mal-estar que dá título ao texto - que se refere à angústia e, mais tarde, ao sentimento de culpa - está associado à ambivalência inscrita na luta constante entre as pulsões de vida e de morte. A repressão à pulsão de morte, à destrutividade e à agressividade do homem é eficiente na sociedade porque "[...] é introjetada, internalizada, mas é propriamente mandada de volta para o lugar de onde veio, é dirigida contra o próprio Eu. Lá é acolhida por uma parte do Eu que se contrapõe ao resto como Super-eu [...]" (FREUD, 2010c[1930], p. 92). Trata-se, assim, da pulsão de morte que foi internalizada pelo sujeito e que produziu a instância psíquica Super-eu que golpeia o Eu e que, assim, serve à auto-observação e à autocrítica.

Para o psicanalista, essa dinâmica, que se refere à constituição da consciência moral, está vinculada à produção do sentimento de culpa presente na maioria dos seres humanos inseridos em sociedade, e que apresenta as bases para uma crítica à cultura que não oferece condições para a singularidade e, quiçá, para a felicidade. $\mathrm{O}$ autor situa esse sentimento como o problema mais importante do progresso cultural, pois demonstra que o peso dos avanços culturais "[...] é a perda da felicidade, pelo acréscimo do sentimento de culpa" (FREUD, 2010c[1930], p. 106).

Pamuk não faz uma crítica explícita à sua cultura, mas aponta a hüzün como o afeto que a caracteriza. Assim, parece haver mais uma postura de compreensão frente às relações de poder entre os países da qual a ruína de Istambul é fruto. Ao mesmo tempo, é como se o romancista alertasse seus leitores para o fato de que a divisão internacional do trabalho e a hierarquia entre os países, que fazem parte da dinâmica capitalista, deixam marcas indeléveis na psique de habitantes de cidades inteiras que são assoladas pelos interesses de lucro e, depois, abandonadas quando não apresentam mais perspectivas de crescimento. Harvey (2005, p. 36) denomina esse processo de deslocamentos espaço-temporais, próprios do avanço tecnológico e da aceleração do tempo histórico na contemporaneidade, nos quais há o abandono de regiões inteiras que não representam mais espaço de circulação de dinheiro e de lucro. Isso causa a devastação da natureza e o desuso de espaços geográficos que deixam rastros de destruição. Sem contar a mão de obra acumulada que é desperdiçada, acarretando desemprego e sofrimento psíquico.

É possível afirmar que tanto Freud quanto Pamuk (2007a) apresentam mais questões do que respostas para os enigmas da vida. $\mathrm{O}$ psicanalista analisou o sentimento de culpa inerente ao progresso da civilização, situa esse afeto no cerne da constituição da consciência moral, que, apesar das idiossincrasias pessoais, é universal no processo de constituição psíquica, porém encerra seu clássico texto com uma interpelação ao seu leitor: "[...] a questão decisiva para a espécie humana é saber se, e em que medida, a sua evolução cultural poderá controlar as perturbações trazidas à vida comum pelos instintos humanos de agressão e autodestruição" (FREUD, 2010c[1930], p. 122). Por sua vez, o romancista, ao retratar um sentimento que é compartilhado por quem vive na cidade, extrapola as fronteiras entre o Eu e a cultura e revela o que é próprio de um povo. Não para exaltá-lo, 
mas para alertá-lo da força do passado que, infelizmente, insiste em assombrá-lo na intempestividade do presente. A hüzün ultrapassa o espaço da novela familiar e abrange as nuvens e fumaças que invadem a cidade e, assim, parece refletir a memória coletiva de um território. Esta memória diz respeito àquilo que a cidade foi e que lateja na lembrança de seus habitantes, seja por sua paisagem imponderável, seja por meio dos monumentos, livros e enciclopédias. Do ponto de vista da memória singular, cada habitante da cidade, a seu modo, incorpora esse legado que é transmitido pelos jeitos e trejeitos da história oral, como também pela leitura dos documentos e jornais impressos que representam a história oficial.

Talvez o que mais aproxime Pamuk e Freud seja o fato de que toda a constituição psíquica teria que se haver com essas perdas de objetos, reais e imaginários, e com as formas como cada cultura produz estratégias para lidar com os afetos tristes que advêm delas. Perdas e estratégias de superação fazem parte da memória coletiva que remete à herança arcaica do gênero humano que, não necessariamente, precisa ser vista como algo etéreo, mas como fruto das transmissões, entre gerações, de conhecimentos, experiências, costumes e hábitos. Se Freud recorre ao mito como modo de dar forma a essa herança arcaica, Pamuk perscruta a reconstrução real e imaginária da história de seu país para delinear a memória coletiva de seu povo. Outro ponto de aproximação é o de que os dois diferentes tipos de afeto, a hüzün e o sentimento de culpa, podem ser compreendidos como efeitos de uma cultura compartilhada através da história, mas que se manifestam na singularidade do sujeito.

Um sujeito que traz as marcas de seu passado, consciente e inconscientemente, que está mergulhado em sua cultura, mas que pode ascender em singularidade. No caso, Pamuk produz uma escrita por imagens que, ele reconhece, traz o legado da hüzün que constituiu sua forma de ver o mundo. Escolhe, em sua obra aqui em foco, exercitar uma escrita de si que constata o peso do passado e, em decorrência disso, se reinventa no presente.

À luz das ideias de Rancière (2009) é possível qualificar essa aproximação entre Freud e Pamuk. O primeiro autor:

[...] solicita à arte e à poesia que testemunhem positivamente em favor da racionalidade profunda da 'fantasia', que apoiem uma ciência que pretende, de certa forma, repor a poesia e a mitologia no âmago da racionalidade científica. [O segundo recolhe os restos e vestígios das coisas obscuras e triviais e] [...] devolve aos detalhes insignificantes da prosa do mundo sua dupla potência política e significante. [...] $\mathrm{Na}$ topografia de um lugar ou na fisionomia de uma fachada, [...] ele reconhece os elementos de uma mitologia (RANCIERE, 2009, p. 46-48). 


\section{O PENSAMENTO POR IMAGENS: O PROCESSO DE CRIAÇÃo DO AUTOR}

[...] devemos lembrar que a primeira finalidade de um pintor de paisagens é despertar no espectador os mesmos sentimentos que a paisagem evocou no próprio artista (PAMUK, 2007a, p. 103).

Esta epígrafe nos ajuda a refletir sobre como a escrita de Pamuk se inspira nos quadros, fotografias e cartões-postais que têm como tema a cidade de Istambul. Essas imagens são transpostas para a linguagem escrita do romancista e visam suscitar, em seus leitores, os mesmos afetos que a experiência de vida na cidade evocou no escritor. Ele apresenta as fotografias e os quadros expostos no livro por meio de descrições meticulosas do que está nas imagens. Ao descrevê-las para os leitores, o romancista pode suscitar neles a atenção para um detalhe na figura que, provavelmente, não seria percebido em sua magnificência sem as dicas escritas no livro. É como se houvesse uma aposta no fato de que essas descrições ampliariam a percepção e a imaginação dos leitores, pois são frutos das associações entre diferentes linguagens, entre o que está na fotografia, na gravura, no quadro do pintor e na produção escrita. Entre o visto e a escrita sobre aquilo que se vê, é possível, em alguns casos, reviver situações e acasos.

Aliás, o escritor compartilha com seus leitores como foi o processo de escolha das fotografias para o livro:

Revivi boa parte das emoções e da perplexidade de escrever este livro enquanto escolhia as fotografias. [...] foi como se minha própria memória tivesse sido projetada em uma tela; houve outros momentos parecidos, quando eu era tomado por um frenesi de capturar e preservar essa paisagem de sonho para poder escrever sobre ela (PAMUK, 2007a, p. 387-388).

A partir desse trecho, é possível afirmar que o que alimenta o processo de criação do romancista são as imagens, mantidas como referência e inspiração. Mais do que isso, ele faz questão de apresentar as possíveis tonalidades desse conteúdo imagético. As lembranças também são coloridas e, assim, é como se a memória fosse um mosaico de cores que pigmentam o imaginário. Nesse sentido, os matizes dos quadros, assim como os da cidade, são apresentados pelo autor; o alaranjado e as tonalidades tênues da época do império são contrastados com o cinza e o preto e branco no hodierno:

Meus contemporâneos tendem a desconsiderar os guaches de cores sutis da Istambul imperial; [...], e por razões de conveniência, preferem ver o seu passado em representações monocromáticas mais fáceis de reproduzir, pois, quando contemplam uma imagem despojada de cor, veem sua melancolia confirmada (PAMUK, 2007a, p. 55). 
O romancista descreve a carga metafórica da gravura de Thomas Allom (1804-1872), exposta num livro de viagens de 1839, que aproxima a cidade da escuridão como fonte do mal e captura a chamada cultura "lunar" de Istambul. Pamuk (2007a, p. 55) nos alerta de que não foram só os viajantes e artistas ocidentais " $[. .$.$] que usaram a linguagem da noite para descrever os mistérios im-$ penetráveis da cidade", mas os próprios Istanbullus, que gostavam de contar, no crepúsculo, as histórias de moças assassinadas no harém e que, logo depois, eram atiradas ao mar. É como se esse clima taciturno e amedrontador fosse uma transmissão simbólica repetida nas histórias contadas pelos diversos habitantes que atravessaram várias gerações da cidade.

No capítulo "Os Prazeres da Pintura", há a descrição de uma fotografia de Ara Güler (1928) que capta as ruelas de sua infância:

O que me atrai nessa fotografia não são só as ruas e as calçadas de pedra, as grades de ferro nas janelas [...] - é antes a sugestão de que, com o cair da noite que acaba de chegar, aquelas duas pessoas que arrastam consigo suas sombras alongadas a caminho de casa estão na verdade estendendo o cobertor da noite sobre a cidade inteira (PAMUK, 2007a, p. 45).

É como se o romancista pudesse criar uma história para cada imagem que advém de seu modo singular de traduzir a arte. Para ele, tudo aquilo opera sentido e, com seu dom de transformar palavras em emoções, faz com que os leitores também se sintam da mesma forma, inseridos no contexto. Consegue, assim, observar com olhos que não somente veem, mas dão vida por meio das palavras que transmite.

Além das imagens e suas cores, o romancista também compartilha conosco outra fonte de inspiração que é o prazer que sente ao transitar, exercitar o papel de passante pelas ruas da cidade. Escolhendo as ruelas mais estreitas e escuras, de preferência as que tenham vista para o Bósforo, para contemplá-las, mas também para dar livre fluxo a seus pensamentos e devaneios. Relata as grandes discussões travadas com sua mãe quando o pai demorava para chegar à noite ou já não estava morando mais com a família. Discutiam a respeito da profissão a seguir, pois já havia abandonado a faculdade de arquitetura e, mais do que isso, do receio que ela tinha de que seu filho fosse artista:

Quando você era pequeno, mesmo quando as coisas iam mal, [...]; você inventava alguma coisa e ficava brincando alegremente horas a fio [...]. Uma pessoa assim se transformar num artista perturbado e miserável sempre puxando o saco dos ricos - mesmo que eu não fosse a sua mãe, não poderia aguentar essa transformação. E é por isso que quero que você me escute, e não se ofenda com o que eu the digo (PAMUK, 2007a, p. 382).

Depois dessas discussões, Pamuk (2007a, p. 385) caminhava a esmo pelas ruas da cidade e, no transcorrer de algum tempo, voltava para casa, sentava à mesa e tentava "capturar a química daquelas ruas no papel". Assim, avultava nele jun- 
to, com o desejo de caminhar, a necessidade de exercitar sua arte. A despeito dos conselhos de sua mãe, a arte emergia como algo necessário e iminente para sua sobrevivência, justamente, e ao contrário da visão materna, era isso que o auxiliava a não se transformar num "perturbado". Parece que o romancista compartilha com seus leitores a ideia da arte como necessária e propulsora da pulsão de vida:

Os passeios que eu dava nessa época às vezes duravam horas, e em certos casos, quando eu já tinha caminhado pelo tempo suficiente $-[\ldots]$, às vezes eu sentia um outro impulso irresistível: o desejo de voltar para casa e pôr essas imagens em palavras escritas, encontrar a linguagem capaz de exprimir aquela disposição negra, aquela confusão cansada e misteriosa. Era um desejo tão irreprimível quanto o velho impulso de pintar, mas eu não sabia ao certo o que fazer com ele (PAMUK, 2007a, p. 376).

Nesse trecho, a arte aparece como necessidade e como desejo irreprimível. Este último está relacionado ao fato de que o romancista registra o como transforma o sentimento melancólico em propulsão para a criação, andar até se cansar fisicamente, voltar para casa e cansar a mente, transformar aquela disposição negra e indizível em algo que poderia ser transmitido simbolicamente para o papel por meio da arte da escrita. Seria o romancista através de sua arte capaz de transformar pulsão de morte em pulsão de vida? Ou hábil em metabolizar o ensimesmamento próprio do melancólico em produção escrita reconhecida mundialmente?

A arte como necessidade parece emergir quanto refletimos sobre o fato de que o romancista não recebeu incentivos para desenvolver a arte da escrita por parte de seus familiares, além de que não é filho de artistas nem de escritores; ao contrário, é descendente de uma família tradicional turca, burguesa e abastada o que facilitou seu acesso aos melhores colégios e universidades do país -, cuja mãe era dona de casa e o pai era um péssimo administrador, que muitas vezes perdia boa parte do patrimônio herdado de seus ancestrais. A avó, viúva desde muito cedo, era a figura central da casa que, sempre em seu quarto, deitada ou sentada na cama, oferecera a ele as primeiras incursões pelas letras do alfabeto. O escritor confessa que todo professor parecia meio sem graça perto dos ensinamentos da avó. Mas foi na relação com o pai que se construíram os primeiros passos na literatura, cuja influência só foi reconhecida tardiamente e tornada pública no discurso proferido na cerimônia na qual recebeu o prêmio Nobel (PAMUK, 2007b).

O romancista começou a escrever aos 23 anos, mas essa escolha não foi fácil, nem conscientemente planejada. Refletiu transições nas quais, na infância, desenhava compulsivamente, de modo que, na escola e em casa, angariava elogios dos professores e familiares. $\mathrm{Na}$ adolescência, foram várias as tentativas de elevar-se ao patamar de um pintor de paisagens reconhecido e famoso. Em sua obra, tem produzido uma literatura feita de um pensamento que se expressa por imagens. Daí as fotografias que entremeiam as páginas do livro aqui em foco, cujas descrições cuidadosas do autor ampliam a beleza das imagens, delineando detalhes que realçam o todo dessas figuras. 


\section{II.1. DEVAneio E CRIATIVIDADE NO PROCESSO DE PRODUÇÃo ESCRITA}

A ocupação favorita e mais intensa da criança é o brinquedo e os jogos. Acaso não poderíamos dizer que ao brincar toda criança se comporta como um escritor criativo, pois cria um mundo próprio, ou melhor reajusta os elementos de seu mundo de uma nova forma que lhe agrade? (FREUD, 1976a[1908], p. 149).

Pamuk considera a importância de sua infância e da liberdade que tinha para fantasiar e devanear nos longos dias em que ficava dentro de casa. Contudo, isso não se referia a um sentimento de infelicidade, mas sim à necessidade de escapar da clausura em que vivia no apartamento do prédio da família, no qual primos e tios ocupavam os outros andares, cujo ponto central era o quarto da avó. Para ele, a fantasia era uma forma de escapar do confinamento daquela casa " [... ] sombria e abafada que rejeitava [...] qualquer sugestão de espiritualidade, amor, arte, literatura ou até mitologia [...]". Assim, declara: “[...] se de tempos em tempos eu me refugiava num outro mundo, não era porque eu fosse infeliz. [...] Se eu tinha algum tipo de queixa, era a minha incapacidade de enxergar através das paredes" (PAMUK, 2007a, p. 33).

Nessa citação, o narrador está na pele de suas percepções infantis e, em outro trecho, compartilha com seus leitores como os adultos eram vistos por seu olhar de criança: eram pesados, desajeitados e realistas em demasia. Ele arrisca uma hipótese sobre as pessoas mais velhas: "Pode ser que no passado tivessem tido algum conhecimento de um outro mundo oculto, mas pareciam ter perdido sua capacidade de admirar-se e esquecido de como se sonha [...]" (PAMUK, 2007a, p. 35).

O pai, entre todos na família, era o que não via problemas nessa inclinação devaneadora do escritor: "A única pessoa que parecia perceber a existência de meu mundo secreto de fantasia era o meu pai" (PAMUK, 2007a, p. 32). Nessa época, o passatempo predileto do romancista era ficar observando a cidade por horas a fio, muitas vezes através de uma janela embaçada, como se ele não fizesse parte deste mundo e precisasse criar um outro para viver. Sua primeira forma de expressão artística, ainda na infância e, assim, durante muito tempo, associava sua tendência para os devaneios com a habilidade de criar formas no papel. Adorava quando mostrava suas figuras a seu pai, pois "[...] toda vez ele tinha o tipo de reação que eu preferia: primeiro examinava o desenho com espanto e uma admiração que sempre me deixavam sem fôlego, e depois o interpretava" (PAMUK, 2007a, p. 159). A apreciação de seu pai muito se assemelhava, ou possuía sua parcela de influência, à forma de conceber o mundo do próprio escritor:

Olha como é lindo o modo como você desenhou esse pescador de pé. É porque ele está de mau humor que o mar está tão escuro. E deve ser o filho dele ao seu lado. As aves e os peixes também parecem estar esperando. Que perspicaz você (PAMUK, 2007a, p. 159). 
E, em seguida, ainda confessa que: "[...] Mesmo mais tarde, quando me vi capaz de ler um livro perfeitamente bem, o que importava mais não era 'entender' o que o texto dizia, mas suplementar seu significado com as fantasias certas" (PAMUK, 2007a, p. 31). Sua preferência pela própria compreensão acerca de tudo a partir das sensações e principalmente das imagens talvez nos dê um norte sobre seu processo de criação, que ocorre por meio do devanear, do fantasiar e da produção de um pensamento por imagens aliado às próprias experiências decifradas por ele.

Pamuk parece se esforçar em todo o livro para não perder seu olhar infantil para as coisas da vida. Exercita um papel de narrador, que vai da criança ao adulto cinquentão, como se ele fosse amadurecendo até as últimas páginas do livro, momento no qual ele se reconhece como escritor e assume como sua profissão a arte da escrita.

No texto "Escritores criativos e devaneio", Freud (1976a[1908]) faz homologias entre o brincar da criança, os jogos infantis, as fantasias e o processo criativo dos escritores. O psicanalista nos adverte que a antítese do brincar não é o que é sério, mas o que é real. Nos jogos e na brincadeira, a criança exercitaria a capacidade de criar um mundo de fantasias repleto de devaneios:

$\mathrm{O}$ escritor criativo faz o mesmo que a criança que brinca. Cria um mundo de fantasia que ele leva muito a sério, isto é, no qual investe uma grande quantidade de emoção enquanto mantém uma separação nítida entre o mundo e a realidade (FREUD, 1976a[1908], p. 150).

Freud (1976a[1908], p. 149) abre seu texto com as seguintes questões: quais seriam as fontes das quais o escritor criativo retira seu material e como ele consegue impressionar e despertar emoções em seus leitores?

No que se refere ao primeiro ponto de curiosidade de Freud, parece que Pamuk não é parcimonioso nesse quesito e desde o início relata que sua fonte de inspiração, de onde retira seu material, é a cidade de Istambul, cujas arquitetura e leitura do afeto produzido nela só foram possíveis porque o romancista, além dos devaneios de criança, ficava horas a fio observando a cidade e era um leitor assíduo e voraz de autores nativos e estrangeiros que escolhiam Istambul como tema. Portanto, o olhar que o romancista constrói e lança sobre a cidade é fruto de sua leitura minuciosa e atenta dos literatos que também foram influenciados pela produção intelectual ocidental e, mais do que isso, pela própria visão dos estrangeiros quando escreviam sobre a experiência de conhecer e transitar por esse território.

O romancista reconhece (cf. IMBRIZI; MATSUBARA; SILVA, 2013) a influência das produções culturais e artísticas sobre sua própria formação e visão de mundo. O legado dos elogios a Istambul e a descrição de seus panoramas melancólicos advieram de autores estrangeiros, mas seus heróis são os escritores turcos, retratados como marginais e solitários: Yahya Kemal (1884-1958), Ahmet H. Tampinar (1901-1962), Abdülhak S. Hisar (1887-1963) e Resat E. Koçu (19051975). Este último publicou uma enciclopédia em fascículos sobre a cidade. 
Mas foram os poemas, romances, contos, artigos, memórias e enciclopédias desses quatro heróis, de quem falarei de tempos em tempos neste livro, que abriram os meus olhos para a alma da cidade em que vivo. Pois estes quatro escritores melancólicos extraíram suas forças das tensões entre o passado e o presente, ou entre o que os ocidentais preferem chamar de Oriente e Ocidente; foram eles que ensinaram como conciliar o meu amor pela arte moderna e a literatura ocidental com a cultura da cidade em que vivo (PAMUK, 2007a, p. 121).

Nessa citação, o romancista assinala que não há purismo, mas sim uma cultura híbrida de elementos à primeira vista díspares e incompatíveis. Este parece ser um importante efeito produzido no contato com o tipo de literatura produzida por Orhan: convidar seus leitores para a convivência e para a partilha de espaço e tempo com o estrangeiro, exótico e estranho.

Freud (1976a[1908]) também está interessado nos possíveis efeitos da literatura na vida dos leitores. Isso se refere ao segundo ponto de sua curiosidade: como o escritor consegue impressionar seus leitores a ponto de despertar emoções das quais talvez nem eles se julgassem capazes de sentir. Para o psicanalista, essa suposta insensibilidade de alguns leitores faz referência ao processo de socialização que produz no adulto certa dificuldade em dar vazão a jogos imaginativos. A passagem da infância para a maturidade faz com que esses momentos sejam esquecidos e, muitas vezes, encaminhados para uma região da mente bem longe da consciência. Em decorrência disso, a maioria dos adultos sente uma espécie de vergonha frente às situações nas quais são convidados a brincar ou a fantasiar. Para alguns deles há até um sentimento de repulsa e, assim, devaneios e fantasias só são permitidos durante a calada da noite e, no limite, na imprevisibilidade dos conteúdos oníricos. Alguns adultos ainda podem encontrar outro tipo de saída, que é refletir sobre a intensa seriedade com que realizavam seus jogos na infância, equiparando suas ocupações do presente com os jogos infantis, e só assim conseguiriam "[...] livrar-se da pesada carga imposta pela vida e conquistar o intenso prazer proporcionado pelo humor" (FREUD, 1976a[1908], p. 150). Assim, o senso de humor seria uma forma de se avizinhar das fantasias e da capacidade imaginativa que foram suprimidas pelo tipo de verniz civilizatório exigido dos adultos no capitalismo.

Freud sugere que o escritor criativo consegue efeitos emocionais nos leitores graças ao caráter estético da apresentação de suas fantasias e, a despeito da ideia de que "como" o escritor consegue fazê-lo seja um segredo, trata de valorizar que há algo nesses escritos que supera o sentimento de repulsa (ou aparente desinteresse) ligado às barreiras que separam cada Eu dos demais. Por isso é possível que ocorra a vivência do prazer estético, que resulta da libertação de tensões em nossa mente quando nos encontramos com e quando estamos sob o efeito da leitura de uma obra literária: 
A verdadeira ars poética está na técnica de superar este nosso sentimento de repulsa [...]. Podemos perceber dois dos métodos empregados por esta técnica. $\mathrm{O}$ escritor suaviza o caráter de seus devaneios egoístas por meio de alterações e disfarces, e nos suborna com o prazer [...] estético que nos oferece na apresentação de suas fantasias. Denominamos de prêmio de estímulo ou de prazer preliminar ao prazer deste gênero que nos é oferecido para possibilitar a liberação de um prazer ainda maior, proveniente de fontes psíquicas mais profundas. Em minha opinião, [...] a verdadeira satisfação que usufruímos de uma obra literária procede de uma liberação de tensões em nossas mentes (FREUD, 1976a[1908], p. 158).

Freud reconhece, portanto, os diferentes estados afetivos que podem ser produzidos no leitor em decorrência do contato com a literatura. Entre eles, a diminuição de tensões estaria relacionada à possibilidade de suscitar, nos leitores, menos pudores no que se refere a compartilhar e aceitar as próprias fantasias e mestria imaginativa e, quiçá, até se deleitar com seus devaneios.

Podemos inferir que a leitura do livro Istambul teria a potência de produzir em seu leitor no mínimo dois movimentos: o desejo de se transportar para a cidade turca e se aproximar das experiências relatadas no livro. Por outro lado, possibilitaria produzir nos leitores a curiosidade por sua própria cidade natal, sua história, sua arquitetura, que potencializariam certo orgulho e/ou vergonha desse território que, bem ou mal, é parte da constituição do sujeito. Nesse sentido, o livro é uma obra de arte que interpela o leitor (cf. FAVARETTO, 2011) na direção de instigá-lo a refletir como seu Eu está constituído pelas belezas e horrores das cidades onde nasceu, viveu ou apenas esteve de passagem.

Assim, como afirma Freud, mesmo se descobríssemos qual é e como se faz a escolha do material pelo escritor e a "natureza da arte de criação imaginativa", isso, infelizmente, "[...] em nada irá contribuir para "nos tornar" escritores criativos" (FREUD, 1976a[1908], p. 149). Mas, a despeito de concordarmos com Freud, pensamos, por outro lado, que a exposição frequente à leitura dos textos imaginativos dos escritores criativos talvez autorize esses leitores a romper, de vez em quando, com a aceleração do tempo histórico e, assim, soltar as rédeas que os prendem ao cotidiano e os impedem de devanear. A despeito disso, poderiam ousar ser artistas da própria vida, em busca da reinvenção de jeitos que resistam às pressões dos modos hegemônicos de existência.

\section{À guisa de CONClusão}

Janelas embaçadas me fazem sentir hüzün, e ainda adoro me aproximar dessas janelas para traçar palavras nelas com a ponta do dedo. À medida que dou forma a palavras e figuras na janela embaçada, a hüzün dentro de mim se dissipa e consigo relaxar; depois que acabo de escrever e desenhar posso apagar tudo com as costas das mãos e olhar para fora [...] (PAMUK, 2007a, p. 98-99).

Fractal, Rev. Psicol., v. 26 - n. esp., p. 695-714, 2014 
Nessa epígrafe, escrever e desenhar funcionam, para o romancista, como um tempo de transição entre o sentimento de hüzün e o contato que pode ser estabelecido com o mundo externo. Esta parece ser a beleza das várias formas de arte: produzir no "entre" a subjetividade e a cultura, criando continuidades. Arte como esse ínterim e como espaço ocupado pela criação, cuja possibilidade está em convergir dois mundos e, assim, produzir a diferença, o novo e a singularidade. No livro de Pamuk, esse intervalo aparece como a arte de narrar a história de uma vida. Nele, o romancista exercita a escrita de si entremeada com a história de sua cidade natal e, assim, produz um deslocamento entre o visível e o invisível e entre o dizível e o indizível. Enfatiza o que pode ser visto em seus passeios a esmo pelas ruas de Istambul, nas horas dissipadas observando o Bósforo e na relação que estabelece entre fotografia e memória. Assinala o que escapa à visão, o imponderável, ao retratar um afeto que esfumaça toda uma cidade e ao insistir em escrever sobre o que, aparentemente, seria indizível.

Outro ponto a se destacar na arte de narrar de Pamuk localiza-se na contramão do estilo de uma escrita confessional que apresenta uma ordem linear do tempo e que coloca o herói da história vencendo todas as intempéries da vida enclausurado na busca por evidenciar somente suas verdades individualizantes -, como se seu bem-estar e sua saúde dependessem da máxima exposição de sua intimidade. Nessa contracorrente, o romancista convida os leitores para refletir como o seu Eu está ceifado pela topografia de sua cidade natal, escreve sobre si e sua família, ao mesmo tempo em que delineia as peculiaridades da cultura de Istambul. Ao contrário de enfatizar a linearidade de sua trajetória de vida, propõe um movimento extemporâneo no qual ocupa a posição de um narrador que oscila entre o lugar da criança, do adolescente e do adulto, cujas lembranças são transpostas para a escrita no livro. É o tempo do inconsciente e das experiências subjetivas do escritor que povoam o livro. A despeito disso, o romancista compartilha com seus leitores o fato de que espaço e tempo se misturam na escrita de suas reminiscências. Ao descrever suas experiências, reflete sobre o peso da memória coletiva que embaralha fato e ficção. Se há alguma posição para o herói nessa história, é a daquele que ocupa o lugar do protagonista extremamente frágil que sofre com o peso do passado na intempestividade do presente. A despeito dos receios da mãe, que não queria um filho artista, o herói percebe que essa é sua única alternativa de vida, calcada em seu desejo irreprimível de desenhar e de escrever sobre a melancolia que impregna sua cidade natal. Esse protagonista nega os extremos ao não reproduzir o estereótipo do artista, seja o daquele que está acima de todos os mortais e da própria cultura, seja o do inútil e perturbado por não ocupar um lugar condizente com os critérios de produtividade e, assim, recusa o lugar do gênio inacessível e de louco irascível. Antes de tudo, nosso herói é um homem comum, com temores e paixões, que explicita de onde recolhe o material para sua imaginação: do cotidiano e do amor por sua cidade natal. Apanha, assim, os restos deixados por outros artistas da imagem e da escrita, principalmente os aparatos produzidos por seus escritores favoritos, retratados como solitários, marginais e melancólicos. O romancista faz, então, um belíssimo movimento de deslocamento entre a arte e a vida. 
Assim, nos aproximamos das ideias de Favaretto (2011), para quem a arte no contemporâneo, para além de seus possíveis efeitos para a subjetividade, interpela o sujeito e o deixa frente a frente com o inesperado e com aquelas memórias que a história oficial faz questão que ele se lembre de esquecer.

Por outro lado, ao nos avizinharmos das ideias de Freud, localizamos o estranho neste livro de Pamuk, no momento mesmo em que somos convidados a refletir sobre os afetos peculiares que afloram na cidade. No sentido mesmo em que o romancista insiste em revelar o que teima em permanecer latente nos escombros e restos deixados pela arquitetura do Império Otomano. Há uma narrativa do $\mathrm{Eu}$ na qual o pensamento se estende entre a arte, a ciência, a superstição e a mitologia.

No que se refere aos afetos, tanto o romancista como o psicanalista nos convidam para refletir sobre a memória coletiva e a herança arcaica que marcam nossos modos de existência. Melancolia e sentimento de culpa, perda de objetos e morte do pai são entremeados pelo amor e ódio que sintetizam a ambivalência de sentimentos frente ao que foi extraviado e suas possibilidades de superação. $\mathrm{O}$ que nos incita a pensar a arte como potência de vida que, na luta irascível contra as pulsões de morte, pode possibilitar a transformação do sofrimento advindo de nossos lutos e melancolias em movimento, na direção de novos modos de existência.

Pamuk, por sua vez, com sua escrita parece estabelecer uma ponte entre dois mundos que não se separam, mas estão em continuidade: o dos objetos perdidos e restaurados e o dos sentimentos de perda e de superação. Essa ponte nos incita a enxergar as possibilidades de invenção de um sujeito que se liberta das amarras de seu contexto social por meio da escrita das memórias de sua vida. Assim fazendo, ele nos alerta para o fato de que, para narrar a história de sua vida, é importante que o sujeito trace um movimento necessário e humilde de aceitação do lugar de origem que o constituiu e só então ouse se reinventar sem ressentimentos. No que se refere à invenção, tanto o psicanalista quanto o romancista a associaram ao fantasiar e ao devanear que, por sua vez, estão ligados ao desejo de reconstruir a realidade insatisfatória e de criar modos mais bem-humorados de estar no mundo.

Em síntese, os dois autores aqui em foco aproximam-se do regime estético da arte (RANCIÈRE, 2009) no qual as coisas da arte são coisas do pensamento e, assim, podem criar modos inusitados do pensar a vida, a sociedade e a realidade. Nesse sentido, foi possível aproximar a literatura de Pamuk das ideias de Freud, pois os dois fazem parte de uma revolução estética que revela o horror e o imponderável do sofrimento, como também a beleza e a possibilidade de superá-lo. Provam e testemunham, cada um a seu modo, que há sentido no que parece não ter, que há o enigmático no que parece ser evidente. Aproximam-se do que seria o movimento próprio da arte, como também das produções do inconsciente.

Freud produziu uma teoria na qual o que causa estranhamento e inquietação está presente na inclusão daquilo que não pode ser expresso por palavras: a catástrofe do saber insuportável e o pathos no pensamento. A despeito disso, os textos “A transitoriedade" (2010a[1916]) e "O “Estranho"” (1976b[1919]) talvez sejam os que mais se aproximem desse regime estético da arte discutido por Rancière: neles há a possibilidade de incluir, como parte da vida, o que causa estra- 
nhamento, o contato com o estranho que nos é familiar e que, por isso, provoca horror e angústia, como também a oportunidade de inserir a questão de apreciar a beleza e os bens culturais, apesar de sua transitoriedade na vida, engolida pela voracidade do tempo no capitalismo. Podemos, assim, considerar que há elementos para apresentar o pensamento que está na arte produzida nos escritos de Pamuk, como obra aberta que suscita estranhamento e aceitação do transitório. Nessa aceitação, há certo exercício: do senso de humor frente às agruras da realidade; de criação e invenção de um presente que, mesmo que parcialmente preso ao passado, não está incrédulo frente às possibilidades do futuro; do jogo, do brincar e do devanear como dimensões da vida.

Antes de encerrarmos o texto, cabe a nós, autoras, refletir sobre o modo de pensamento sobre a arte que propusemos em nossa escrita. Exercitamos o espaço do possível na aproximação "entre" dois campos diversos do saber: a literatura de Orhan Pamuk e a psicanálise de Sigmund Freud.

\section{REFERÊNCIAS}

FAVARETTO, C. Deslocamentos: entre a arte e a vida. ARS, São Paulo, v. 9, n. 18, p. 94-109, 2011. Disponível em: <http://www.revistas.usp.br/ars/article/ view/52788>. Acesso em: 27 abr. 2014.

FREUD, S. Escritores criativos e devaneio (1908). In: SALOMÃO, J. (Org.). Obras Psicológicas Completas de Sigmund Freud. Rio de Janeiro: Imago, 1976a. Edição Standard Brasileira, v. 9, p. 147-158.

FREUD, S. O ‘estranho’ (1919). In: SALOMÃO, J. (Org.). Obras Psicológicas Completas de Sigmund Freud. Rio de Janeiro: Imago, 1976b. v. 17, p. 273-314.

FREUD, S. A transitoriedade (1916). In: SOUZA, P. C. de (Org.). Obras Completas. São Paulo: Companhia das Letras, 2010a. v. 12, p. 247-252.

FREUD, S. Luto e melancolia (1917). In: SOUZA, P. C. de (Org.). Obras Completas. São Paulo: Companhia das Letras, 2010b. v. 12, p. 170-194..

FREUD, S. O mal-estar na civilização (1930). In: SOUZA, P. C. de (Org.). Obras Completas. São Paulo: Companhia das Letras, 2010c. v. 18, p. 13-122.

FUKS, B. Freud e a cultura. São Paulo: J. Zahar, 2009.

HARVEY, D. O "novo" imperialismo: sobre rearranjos espaciotemporais e acumulação mediante despossessão. Margem Esquerda, São Paulo, n. 5, p. 31$41,2005$. 
IMBRIZI, J. M.; MATSUBARA, F. K.; SILVA, M. Na companhia de Orhan Pamuk: contribuições da literatura para a produção de narrativa de história de vida. In: ENCONTRO NACIONAL DE PRÁTICAS SOCIAIS, POLÍTICAS PÚBLICAS E DIREITOS HUMANOS, 17., 2013, Florianópolis. Anais... Florianópolis: UFSC, 2013. Disponível em: <http://www.encontro2013.abrapso. org.br/>. Acesso em: 22 mar. 2014. Apresentação oral na Abrapso.

MARTINI. A.; COELHO JUNIOR, N. E. Novas notas sobre "O Estranho". Tempo Psicanalítico, Rio de Janeiro, v. 42, n. 2, 2010. p. 371-402.

PAMUK, O. Istambul: memória e cidade. São Paulo: Companhia das Letras, 2007a.

PAMUK, O. A maleta do meu pai. São Paulo: Companhia das Letras, 2007b.

RANCIÈRE, J. O inconsciente estético. São Paulo: Editora 34, 2009.

SOUZA, E. L. (2001). Uma estética negativa em Freud. In: SOUZA, E.; TESSLER, E.; SLAVUTSKY, A. (Org.). A invenção de si e do mundo: arte e psicanálise. Porto Alegre: Artes e Ofícios, 2001. p. 125-133.

Recebido em: 02 de julho de 2014 Aceito em: 03 de setembro de 2014 